\title{
Conceptualizing the implementation of Lesson Study in Kazakhstan within a Social Theory framework.
}

\begin{tabular}{|r|l|}
\hline Journal: & International Journal for Lesson and Learning Studies \\
\hline Manuscript ID & IJLLS-08-2019-0060.R1 \\
\hline Manuscript Type: & Research Paper \\
\hline Keywords: & $\begin{array}{l}\text { Kazakhstan, Lesson Study, Social Theory, Critical Realism, Process } \\
\text { Tracing }\end{array}$ \\
\hline \multicolumn{2}{|l}{} \\
\hline
\end{tabular}

SCHOLARONE $^{\text {TM }}$

Manuscripts 
Conceptualizing the implementation of Lesson Study in Kazakhstan within a Social Theory framework.

\section{Abstract}

Purpose: The aim of the study is to provide an analysis of processes in operation during the implementation of a reform programme in Kazakhstan culminating in the widespread adoption of Lesson Study.

\section{Methodology}

The study is positioned within a critical realist theoretical perspective, drawing on Archer's social theory to focus on the social world of the school while changes to classroom practice are being made. This is a case study using process tracing methods to analyse how school actions and interactions are used during the change process resulting in widespread implementation of Lesson Study.

\section{Findings}

Three key mechanisms for implementing the structural changes are identified; increasing teacher's pedagogical knowledge, collaborative working structures and active collective inquiry.

The capacity to change practice is underpinned by reflection on classroom interactions and in having the necessary skills and available time to analyse the effect on pupils' learning. Engaging in reflexive deliberation is dependent on having access to new knowledge, together with the opportunity to collaborate in supportive groups.

\section{Originality / value}

This study provides an insight into what changes were made and why these support the spread of Lesson Study in Kazakhstan, drawing on Archer's social theory and using theory building process tracing methods to delve deeper into the empirical fingerprints left during the intervention. Lesson study is an important structural factor which is still supporting change in Kazakhstani classrooms.

Keywords: Kazakhstan, Lesson Study, social theory, critical realism, process tracing Paper type: Research paper 


\section{INTRODUCTION}

Lesson Study (LS) is now widely recognized as a driver of teacher-led professional development in many education systems around the world (Lewis, 2002;Takashi \& Yushida, 2004; Nakano, 2008; Robinson \& Leikin, 2012; Kim-Eng Lee \& Mun Ling, 2013, Dudley, 2015; Akiba \& Wilkinson, 2015; Hadfield \& Jopling, 2016; Rappleye, J. \& Komatsu, 2017; Elliott, 2019). Recent research provides strong evidence that the LS structure of; reflective cycles, collaborative teacher planning, focussed classroom observation and subsequent analysis, is the foundation for reflective discussion, development and further planning (Prenger, Poortman \& Handelzalts, 2017; Coenders \& Verhoef, 2019; Elliott, 2019; Mayrhofer, 2019; Mynott, 2019; Vermunt et al , 2019 ). However, the precise mechanisms employed and the model of Lesson Study adopted varies depending on the ultimate purpose of using classroom focused development of practice (Norwich, B, 2018; Takahashi \& McDougal, 2019). In the literature, there are examples of Lesson Study being used as a vehicle for curriculum development (Lewis \& Tokashi, 2013; Chen \& Yang, 2013; Tan-Chia, Fang \& Chew Ang, 2013; Kuno, 2015,) and in the development of teaching materials and textbooks. Teachers in Kazakhstan are now also familiar with the benefits of LS (Alimov, 2017; Khokhotva, 2018).

\section{THE CONTEXT OF INTRODUCING LESSON STUDY}

There is a growing global trend by education systems to improve teaching and learning and this is also the case in Kazakhstan. The government of Kazakhstan is committed to improving the educational opportunities of teachers and students (Bridges 2014, OECD 2014). For this reason, a large scale, long term programme of development is underway which has already had a significant effect on reviewing teaching and learning approaches and is, at the time of writing, focussed on updating the curriculum. As a result, teachers' professional development has become a high priority in the reform agenda of the Ministry of Education and Science of the Republic of Kazakhstan (MoESRK). To expedite this process, in May 2011, the MoESRK set up the Centre of Excellence (CoE) under the auspices of the Autonomous Education Organisation (AEO) "Nazarbayev Intellectual Schools" (NIS). An important function of NIS is to serve as centres of research and development in which new approaches to curriculum, pedagogy and assessment are trialled and then 'transferred' across the country (Shamshidinova, Ayubayeva \& Bridges, 2014).

To develop and support the implementation of new programmes, the CoE collaborated with the University of Cambridge's Faculty of Education (FoE) to introduce a three-level programme for inservice teacher education. These programmes were deigned to realign the focus of teaching towards pupil's learning and so a 'bottom up' approach to change was adopted. 
(Insert Figure 1 about here)

Figure 1 provides a summary of the three level cycles of introduction of the CoE programmes. Each cycle of training involved four-week preparatory face to face training in groups of 25 teachers, followed by a further four weeks back in the teachers' own classroom and school piloting new ways of working, culminating in a further four-week period of face to face study and reflection with the same 25 teachers. The first courses focussed on classroom teaching and extended teacher professional knowledge so that teachers increased opportunities for pupils to become independent, self-motivated, engaged, confident, digitally competent, responsible and critically reflective learners. The second stage added coaching and mentoring training of teachers and the third programme supported senior school leaders to carry out whole school development planning so that structures and time were allocated to allow lesson study to grow as a process of collective inquiry. In essence, the in-service CoE multi-level teacher education programme provided further and often new ways of thinking about teaching and learning and different ways of working in schools and classrooms. To help with implementation, systems and structures integral to the programme design promoted the adoption of the programmes. Lesson study was introduced in the CoE programme as an important driver of classroom changes which continues to support the development of teachers' professionalism.

(Insert Figure 2 about here)

Figure 2 shows how Lesson Study has spread in Kazakhstan since it was first introduced in 2012. In 2015, CoE became an official member of the board of the World Association for Lesson Study (WALS) and at the time of writing, LS training teams have gone on to take on the vital role of leading practice-based inquiry both within Kazakhstan and beyond in neighbouring countries.

\section{HOW HAS LESSON STUDY DEVELOPED WITHIN THE COE PROGRAMME}

The ultimate goals of the CoE programme are to increase teachers' professionalism and ensure that the changes to practice and the curriculum are sustained. Prior to the CoE development teachers were required to take part in a regular teacher evaluation process. As a result, there is already a long tradition of teachers observing each other teach. This means that LS was readily adopted because it was perceived as an extension of the established 'Open Lesson' requirement. However, the focus of the open lessons was mostly on teacher performance whilst LS focuses on pupils learning. The next sections will explain how the process of implementing LS was introduced and why LS supports teacher's learning.

\section{Theoretical Framework}


The study reported here is positioned within a critical realist theoretical perspective (Bhaskar 1978) focusing on the processes which take place in the social world of the school and classroom while changes are being made. Archer (2007) argues that the reality of everyday social situations can be usefully reflected by consideration of three fundamental components of social life - structure, agency and culture. Although structure, agency and culture are considered to be discrete factors, in social systems they are always closely interlinked.

Structures related to schools and classrooms are defined in this study as; leadership systems, pupil groupings, teacher groups, access to knowledge sources and approaches adopted by teachers. Agency is defined as the individual and collective actions and interactions and the choices that teachers are allowed to make when adopting subject content and pedagogical methods. Culture is defined as the intentionality and reasoned motivation in teachers' actions based on ideas, beliefs and values about pupils' learning which are deeply held, difficult to uncover and slower to change. Classroom structures such as organisation of groups of learners and the teaching approaches used are created by mutually sustaining cultural schemas based on beliefs about how children learn. The cultural schema is often perpetuated by the use of text books and habitual classroom practices. The CoE programme is based on the premise that it may be possible to change structures by persuading teachers to experiment with different ways of working, supporting them while they do this with pedagogical strategies and evaluation tools so that ultimately there might be sustained changes to cultural schema.

\section{Generative Mechanisms and Morphogenesis}

The frame of reference used to study the change process is based on Archer's (1995) theory of morphogenesis which refers to change, (genesis) in the shape of things (morpho). Archer's morphogenetic model is a retrospective process for explaining social action which describes a continuum from pre-existing structures, the engagement of agents with new structures, and the point at which those structures are reproduced (morphogenesis) in behaviour. Although classroom research is open to subjective interpretations, Archer's 'generative mechanisms' (2017) provides a framework to analyse social relations over the course of time. By digging deeper and identifying structures, agency and culture of the social situation before and after implementing the CoE programmes it may be possible to infer what the mechanisms are which have helped to bring about the changes observed during the research field work. Table one represents the inferred generative mechanism of change for the CoE programmes of which LS forms an important part.

$\mathrm{T} 1$, in Table one, represents the system as it already was before the intervention, which Archer refers to as the structural conditioning. For this study this was a prevailing cultural schema 
dominated by teacher pedagogies which focussed on teachers' performance. At a whole country level, the legacy of the Soviet system was one in which the authorities restricted the ability of teachers to develop a separate professional identity, controlling the degree to which teachers could influence the nature of teacher education, educational research, and the type of professional associations teachers could join (Webber, 2000). Consequently, initial observations of classrooms and interviews with teachers showed that the cultural script prevailing was that of teachers believing that there was no need to change classroom teaching. The argument being that many children in schools received accolades in the form of Olympiad recognition for sciences and mathematics achievement. However, teachers followed the same prescribed curricula, used the same materials and approaches with all the children and believed that the reason that many disaffected students opted out of lessons was because they were 'slow' learners.

The implementation of the CoE programmes is represented by the highlighted part, T2 - T3 in table one. Revised structures were introduced which are designed to challenge the prevailing cultural script and to offer new ideas and ways of working with teacher colleagues and pupils. By definition, Archer's 'Morphogenesis' would be seen to have taken place if new ideas have been adopted and changes have been made to the way of working and interacting in classrooms. T4 represents the situation eight years after the first programmes were introduced. One notable outcome of the overall reform programme has been the widespread embedding of Lesson Study in Kazakhstani schools. There are now teams of trained teachers in virtually all the schools throughout the country who are able to provide a nimble vehicle for bringing about classroom change through active LS groups.

Consequently, there has been a marked shift towards focusing on pupils and planning for all pupils' learning. This claim is supported by strong evidence from published accounts of teachers carrying out Lesson Study in Pedagogical Dialogues, the in-house practice journal, published by Nazarbayev Intellectual Schools, in doctoral studies (Ayubayeva, 2018), teachers' attendance at the World Association of Lesson Study International conferences and in published papers (Alimov, 2017; Khokhtova, 2018).

This paper will focus on how this took place. However, because Archer 's theories are highly abstract Beach \& Pederson's (2013) theory building process tracing methods are also used to delve deeper into actual structures and the mechanisms in action during the process.

(Insert Table One: Morphogenetic Change Sequence about here )

\section{Methodology}


The aim of the study is to understand the processes or mechanisms which were actually in operation during the implementation of the CoE programmes. To this end theory building process tracing methods have been adopted to analyse the 'bottom-up' case-based approach of school and classrooms in actions.

\section{Process tracing methods}

Theory building process tracing methods are widely used to delve deeply into complex changing situations. (Beach \& Pedersen, 2013). Process - tracing attempts to identify the intervening causal process of the sequence of events taking place and account for these through explanatory mechanisms. Mechanisms are not causes, but rather are causal processes that are triggered by changes that link them with outcomes in a productive relationship. In this way process tracing methods are used to observe causal process through close-up qualitative analysis, rather than statistically estimating their effects across multiple cases. The first stage is to identify what the mechanisms are in action during the intervention programme and then analyse how the mechanisms are changing practice.

This paper will use data from a large-scale evaluation programme carried out in 2015 (Wilson, 2016,) relevant findings from $\operatorname{OECD}(2014,2016,2018)$ the World Bank publications (Saber, 2013) and the recently published results of the 2018 TALIS data (OECD, 2019). To understand how LS functions in Kazakhstan requires unpacking the implementation process theoretically and studying this empirically in the form of the traces left by the activities associated with each part of the process.

\section{'Empirical fingerprints'}

In December 2015 there were 7,667 schools across the regions of Kazakhstan, the vast majority (75\%) of these schools are in rural areas where $52 \%$ of the 2.5 million students are educated Data collected early in the implementation stages of the CoE programme in 2013, recorded by two independent external examiners from different UK universities, when they visited schools in the large cities reported that:

"We saw clear evidence of ways in which teachers' practice and their perception of learners is changing. For example, when using collaborative group work and involving pupils in learning activities, teachers reported being surprised by the achievements of children previously judged as 'slower learners". As one teacher said "If you change the strategy, a great deal can be achieved". "The evidence presented by several teachers showed that the children who made the greatest gains were those previously judged as 'cognitively weak'. To challenge deeply held assumptions in this way is a significant achievement of the programme. Across the whole programme, more than 43,820 teachers have successfully completed levels three and two in a remarkably short time" (External Examiners comments 2013). 
In 2015, the CoE research team surveyed a random stratified sample of $3 \%(8,636)$ of the 297,293 teachers using the TALIS (2013) teacher questionnaire and also 3\% (217) of the 7,307 comprehensive schools headteachers using the TALIS principal's questionnaire. 94\% of the 8,636 Kazakhstani teachers who had responded to the teacher questionnaire said that the courses and workshops have made an impact with $60 \%$ believing that this has made a very large impact on their teaching. Furthermore, $60 \%$ of the teacher respondents said that taking part in coaching and mentoring programmes also made a large impact on their practice. In addition, Qualitative data collected in each region included; interviews with teachers and principals, analysis of a range of documentation and observation details form classroom teaching and lesson study groups at work. The CoE report provided evidence of demonstrable changes to teacher professional knowledge and practices, together with evidence that there has been intellectual development and positive changes in attitude and motivation of pupils. By November 2015 there was a critical mass of schools throughout the country where at least one teacher had completed a CoE programme. This means that in 2015 there were over 50,000 teachers in schools throughout Kazakhstan with recent Masters equivalent level qualifications. These teachers had completed a rigorous accreditation process for which they had to demonstrate that they could bring about change in their classrooms and schools. Data collected during school visits showed that access to reading and new approaches had opened up debates about teaching and learning and there had been a marked shift from compliance and passivity among teachers to increased curiosity and agency (Author, 2016). This was corroborated earlier in the 2014 OECD in- country report.

'Kazakhstan has invested much in improving the capacity and the learning conditions in its primary and secondary schools (OECD, 2014d), and the overall educational picture is impressive. '......For teachers, new centres of excellence for pedagogical skills have been established in the NIS network and a three-tier system to train teachers was introduced to help them to upgrade their qualifications.' OECD, 2014, p66.

Furthermore, in all the schools visited, where headteachers had completed the CoE leadership course, whole school staff accountability was a key item in the school development plans. There is strong evidence of teachers' training needs being identified and then individual training being provided though coaching and mentoring programmes in the school. Active knowledge transfer is taking place in schools through embedded Lesson Study groups and Action Research projects with theory and practice closely linked. Also, there are newly created CPD rooms in most schools where teachers meet to discuss teaching and learning and to share their portfolios and handbooks with colleagues who have not attended training.

Research carried out by Yakavets et al in 2017 reported that; 
The practice of sharing experience and coaching by teachers who attended the CoE three-month teacher professional programme was mentioned by nearly all of the participants in the schools we studied. This was seen as an opportunity to build personal and interpersonal capacity within the schools, and overall as a positive development to improve teaching and learning. The school administration was willing to provide better equipped classrooms and different multimedia tools for trained teachers with the aim of advancing sharing practice.

Participants acknowledged that people who attended the COE courses 'are different', namely 'teachers became more democratic'; they were perceived as 'advisors' on new teaching methods in some schools (Yakavets, Frost, \& Khoroshash, 2017, p.356).

The most recent data published in the 2019 OECD report based on the 2018 TALIS data shows that 94\% of Kazakhstani teachers have participated in training based on peer learning and coaching and teachers believe that this collaborative approach to teaching is the most impactful form of learning (OECD, 2019).

$86 \%$ of teachers in Kazakhstan appear satisfied with the training they receive and report that it has a positive impact on their teaching practice. This is higher than the average response for OECD countries in TALIS (82\%). It is also the case that teachers who report participating in collaborative training tend to display higher levels of self-efficacy and job satisfaction.

93\% of Kazakhstani teachers also report that they and their colleagues support each other in implementing new ideas. This is higher than the average response across the OECD countries participating in TALIS (OECD, 2019, p3).

The recent education policy outlook also identifies strengths within the school improvement process of Kazakhstan:

"school-based professional development opportunities for teachers appear frequent and internal discussions to improve practices take place in schools and involve the teaching community' (OECD, 2018, p.13).

(Insert Table Two about here)

\section{Analysing Mechanisms}

What mechanisms are in action? What is changing?

There appears to be three mechanism in operation; increasing teacher pedagogical knowledge, increasing the opportunity to collaborate with other professionals and collective inquiry in LS groups (Table two). The next sections map out these mechanisms and trace the implementation process of LS as it was introduced within CoE programmes.

Developing Teachers' Pedagogical knowledge 
Teachers pedagogical knowledge is understood to be the "deep knowledge about the processes and practices or methods of teaching and learning and how this knowledge encompasses, among other things, overall educational purposes, values, and aims" (Mishra \& Koehler, 2006, p.1026).

LS actively promotes constant consideration of pupils' learning. This feature of Lesson Study is a powerful way to ensure that teachers plan for and focus attention on individual pupils' learning whereas in Open Lessons teachers plan a performance and are judged on how well they carry out the lesson.

Furthermore, within the CoE framework for developing Pedagogical approaches, knowledge sharing is paramount. The collaborative nature of Lesson Study (collaborative planning, after lesson discussion, and the sharing of the results) actually ensures the wider exchange of knowledge but this is made possible because teachers are allowed time to reflect and deliberate on teaching and to collect evidence of pupils' learning. This experience is gained both during the CoE training and later in school- based LS groups. The CoE programme ensures that there are teachers in the majority of schools who have extended pedagogical knowledge and a deeper understanding of how to work collaboratively to ensure that dialogic practices are used by LS groups.

\section{Encouraging Collaboration}

At school level, classroom-based Lesson study promotes collaboration between teachers within and beyond schools as well as collaboration between teachers within their own region and beyond regional boundaries and with more 'knowledge others' (Swaffield,2004). Promoting collaboration and hence building social capital allow informal networks to create webs of understanding, influence, and knowledge (Daly, 2010). Donati (2014) defines social capital as the relational value of trust, cooperation and reciprocity. The formal and informal contacts made during CoE training extend professional networks with strong relationships promoting diffusion of innovation and communication of complex ideas (Daly, 2010). In their recent international review of research on Lesson Study, Xu and Pedder, found twenty-one studies which identified a strong correlation between Lesson Study and teacher collaboration, reporting "an increase in teachers' collegiality, joint decision making, and joint ownership and responsibility for teaching, leading to the cultivation of professional learning communities" (2015, p.40). Given the collaborative and reflective structure of LS, it 
is indisputable that LS can be regarded as a teacher-directed form of professional development.

\section{Facilitating Collective inquiry}

The third mechanism is about setting up structures and allowing teachers to engage in inquiry involving collective reflection on practice. There is a strong emphasis on reflective practice at all levels of the CoE programme where in order to achieve the aims of the programme teachers' written reflective accounts are part of the accreditation process. The premise for this is that in order to improve teaching and learning in Kazakhstani schools, teachers ought to be able to critically evaluate practice within their own classroom and schools, as well as open up their own lessons to scrutiny and to spend time deliberating and writing about this practice. For reflection to be purposeful teachers must believe that they can make a difference to pupils learning and take on the responsibility for this. However, having the will to change things is not enough, teachers need also to understand how to make changes and how to evaluate the effects of these changes on pupil learning. In other words, LS groups encourage teachers to think critically and reflexively (Ricks, 2011; Robinson \& Leikin, 2012) and see themselves as agents of change within their own classrooms and in the wider school setting. The cyclical processes of "plan - teach/observe discuss" structure of Lesson Study provides teachers with the opportunity to engage in collective reflective practice within learning communities (Chichibu \& Kihara, 2013).

\section{HOW ARE THE MECHANISMS CHANGING PRACTICE?}

Beach \& Pedersen (2013) use a machine analogy to help visualize process tracing mechanisms linking a cause and outcome. 'Each part of the theoretical mechanism can be thought of as a toothed wheel that transmits the dynamic causal energy of the causal mechanism to the next toothed wheel, ultimately contributing to producing outcome $Y^{\prime}$ p29. The toothed wheel can be thought of as the entities of the mechanism, which are the people and structures who undertake the activities. The activities are the movements of the wheels which transmit forces through a mechanism (Machamer 2004; Machamer, Darden, and Craver 2000).

(Insert figure three about here) 
In figure three the entities are shown as the cogged wheels and are defined as the components of social life of the classroom, namely; structure, agency and culture of the school (Archer, 2007). In this study, structure is defined; by the leadership roles in place, how teachers and pupils are grouped when they are learning, what access to new knowledge teachers have and the methods used when teachers and pupils learn. Agency is defined as the individual action and collective interactions and choices that learners make in the schools. The prevailing culture will be determined by the deliberative purposive action taken, what motivates teachers and pupils to act and the underlying beliefs.

However, the actual producers of change are the activities which take place and these are shown as the movement arrows in figure 3 . In this analysis there is also a temporal dimension; developing and extending teacher professional knowledge precedes, collaborating to develop professional knowledge which precedes engaging in collective inquiry to develop professional knowledge.

The next sections elaborate on what precisely the activities are which are inferred as having driven change within the entities, the social life of the classroom categorised as structure, agency and culture (Table two). Both activities and entities are expanded on in table two.

\section{Becoming reflexive and deliberating about practice}

For the first stage of the implementation of the CoE programme teachers work for an extended period away from the day to day pressures of school life, allowing them much needed time to read and think without interruption. There are usually twenty teachers in each group from different schools. Working in small groups helps to establish trusting relationships, while working with teachers from other schools brings new ideas and increases reciprocity. Together teachers feel more confident about discussing and thinking through problems. Each group also has a dedicated trainer who acts as a more 'knowledgeable other'. This critical friend role brings new ideas into the school system and facilitates seminars, also creating a trusting and supportive working environment. Although teachers are challenged to justify their way of working this is carried out empathetically and does not threaten teacher identify. Informed professional conversations and inner dialogue are prominent features of this first face to face period. Teachers are asked to examine their beliefs about learning and to think reflexively about specific pupils in their actual classes so they can plan for their own intervention. Throughout the programme there is a conscious 
effort to support teachers in making theory explicit and in linking this theory with actual practice in the teacher's own classrooms. The culmination of the first seminar programme phase is the application of new knowledge. Each teacher carries out a small-scale research study in their own classroom in which teachers collect data about pupils' learning and deliberate about their practice. Immediately after the school based small scale study period, teachers return to the same seminar working groups for a further period of intensive reflection, writing and preparation of a portfolio for accreditation. It is this intensive reflection on the process of studying actual practice which is highly transformational. Indeed, in interviews carried out with teachers, after attendance at a CoE programme and in follow up visits to classrooms sometime later, showed that teacher had revised their beliefs about how children learn and had changed their way of working to make their classroom more inclusive (Wilson, 2016). It is this period of intensive learning to become a reflexive teacher which is the vital first step towards being able to set up successful LS groups. If changes are to be made then teachers must be able to deliberate on practice and take a full part in functioning dialogic LS groupings.

\section{Collaborating with experienced peers and new teachers to spread ideas.}

The second part of the generative mechanism follows the same blended pattern of integrating theory, practice and reflection but focuses on educating experienced teachers about the rationale and operation of coaching teachers who are peers and also on mentoring more junior new teachers. In order to gain accreditation, the coaches are required to work with a peer to diagnose an area to improve, to review evidence about the problem and discuss ways of changing the situation. The programme helps the coach to share the literal professional knowledge content of the CoE programme as well as practical help with on how to create a safe forum for professional dialogue and reflexivity to take place. This interim step of understanding how to motivate teachers to take part in LS groups means that experienced trained coaches are able to counter scepticism, censure and hostility to change. However, the joint planning and implementation is entered into willingly by teachers who want to develop practice, rather than by coercion by senior leaders. In this situation collaboration implies working on co planning and deliberating together and goes beyond following instrumental scripts to implement a task. 


\section{Engaging in LS collective inquiry groups}

The final stage is the establishment of collective LS inquiry groups. There is really strong evidence that LS has spread and been taken up by the majority of Kazakhstani schools (Saber, 2013; Wilson, 2016; Alimov, 2017; Yakavets et al, 2017; Ayubayeva, 2018; Khokhotva, 2018; TALIS, 2019). LS groups are often set up by teachers who have been educated through the CoE programme and so have both pedagogical knowledge and skills to be able to coach peers and lead change within the schools. This is captured in the following statement taken from a recent doctoral study;

'I have completed the third-level CoE course for trainers. I can now work as a teacher trainer. I also trained a cohort of teachers from mainstreams schools before I joined this school. They all did well. Wednesday is the methodological day in our school. We have creative groups consisting of five teachers in each group. On this day, we conduct master-classes and share our experiences with our colleagues' Ayubayeva, 2018, p249

Kazakhstani collaborative LS groups have common features.

1) Shared goals; LS groups have shared goals and seek to solve context specific problems by working together.

2) School structures; The collaborative LS groups are part of structural additions to the whole school development process.

3) Time allocated; There is a significant amount of time spent on planning and reflecting on new ideas and approaches.

4) Reciprocity; The CoE trained teachers bring in new materials to the professional conversations. However, experienced teachers with many years of service in the school, who know the pupils well, also provide important expertise.

5) Sustained Regular Meetings; The LS groups meet regularly over an extended period of time and have established trusting relationships, where open and honest reflective dialogue takes place.

6) Focus on pupils; Most importantly there has been a real shift in focus onto the pupils and their learning, and this is captured in the following statement.

'You see, we never put ourselves into the students' shoes. Once we became the students, we could see the real struggle that they go through. I appreciated this approach so much. I will be better off in planning my lessons from now on' (Ayubayeva, 2018, p250).

\section{CONCLUSION}


Archer 's theories are highly abstract and so there is a danger that theory could over-determine the data. Therefore, process tracing methods have also been used to delve deeper into actual structures and cultures in an endeavour to increase the objectivity of the study so that justifiable arguments can be made.

What do teachers do exactly?

In the schools who embrace change, teachers work together to create new lesson sequences which are inclusive for all pupils. These schools have access to new pedagogical knowledge about extended ways of working and allow teachers time to experiment in classrooms to extend classroom practice. Teachers suggest that it is the chance to think and make collaborative judgments and that this has the biggest effect on changing practice.

Why do some teachers change their practice?

Teachers who commit to changing their practice have common values based on the belief that although pupils are different, they are all equally deserving of the teacher's time and effort. Many teachers are driven by a desire to improve their practices and increase their professionalism so that they can do their job well. Teachers who have been supported to attend courses feel duty bound to share their new knowledge and written support materials with colleagues in schools.

\section{Theoretical explanation}

This paper argues that the capacity to change practice is underpinned by being able to reflect on what is happening in classrooms and having the skills and time required to analyse the effect this has on pupils' learning. Engaging in reflexive deliberation is dependent on two structural factors, access to new knowledge and the opportunity to collaborate in supportive groups. The chain of events which shapes the structural situation in turn allows recurrent reflection on practice to happen. As a consequence, teacher agency is promoted through reflexive deliberation, or inner conversation. This activity constitutes personal power or capacity that emerges in significant part from the practical demands of operating within authentic classrooms. This authenticity, together with the time, space and knowledge plays an important role in determining why individual teachers act within the same socio-cultural context. This dependency is mediated through activity, such as exercising of powers of reflexive deliberation and the occurrence of social interaction over time. Teachers are enabled because of increased access to new knowledge, increased opportunity to collaborate and engaging in collective inquiry. It is these interactions which appear to have brought about social change in the schools and a redrafting of the cultural script.

\section{REFERENCES}


Akiba, M. \& Wilkinson, B. (2016), Adopting an International Innovation for Teacher Professional Development: State and District Approaches to Lesson Study in Florida, Journal of Teacher Education, Vol. 67, No. 1, pp. 74-93.

Akimova, T. \& Wilson, E. (2019), Lesson Study in Kazakhstan, School-wide implementation of Lesson Study: an international perspective, World Association of Lesson Studies conference, Amsterdam.

Alimov, A. (2017), Lesson Study Groups as the Tool of Teachers' Effective Professional Development, Pedagogical Dialogue, Vol. 4, No. 22, pp. $38-42$.

Archer, Margaret. (1995), Realist social theory: the morphogenetic approach, Cambridge University Press, Cambridge.

Archer, M. (1996). Social Integration and System Integration: Developing the Distinction. Sociology, Vol. 30, No. 4, pp. 679-699.

Archer, M. (2007), Making our Way through the World: Human Reflexivity and Social Mobility, Cambridge University Press, Cambridge.

Archer, M. (2010), Conversations About Reflexivity, Routledge, London and New York.

Ayubayeva, N. (2018), Teacher collaboration for professional learning: Case studies of three schools in Kazakhstan, Unpublished thesis. Faculty of Education, University of Cambridge, June 2018.

Beach, D. \& Pedersen, R. (2013), Process-Tracing Methods: Foundations and Guidelines. University of Michigan Press, Ann Arbor, Michigan.

Bridges, D. (Ed), (2014), Education Reform and Internationalisation: The Case of School Reform in Kazakhstan, Cambridge University Press, Cambridge.

Chen, X. and Yang, F. (2013), Chinese teachers' reconstruction of the curriculum reform through lesson study, International Journal for Lesson and Learning Studies, Vol. 2 No. 3, pp. 218-236.

Chen, X. (2017), Theorizing Chinese lesson study from a cultural perspective, International Journal for Lesson and Learning Studies, Vol. 6 No. 4, pp. 283-292.

Chichibu, T. and Kihara, T. (2013), How Japanese schools build a professional learning community by lesson study, International Journal for Lesson and Learning Studies, Vol. 2, No. 1, pp. 12-25.

Coenders, F. \& Verhoef, N. (2019), Lesson Study: professional development (PD) for beginning and experienced teachers, Professional Development in Education, Vol. 45, No 2, pp. 217-230.

Daly, A. (2010), Social Network Theory and Educational Change, Harvard Education Press, Cambridge.

Dudley, P. (Ed.), (2015), Lesson Study: Professional Learning for our time, Routledge, London.

Elliott J. (2019) What is Lesson Study? European Journal of Education, early Online 00, pp 1-14

Coenders, F. \& Verhoef, N. (2019), Lesson Study: professional development (PD) for beginning and experienced teachers, Professional Development in Education, Vol. 45 No. 2, pp. 217-230.

Fullan, M. \& Hargreaves, A. (2016), Bringing the profession back in: Call to action, Learning Forward, Oxford. 
Hadfield, M. \& Jopling, M. (2016), Problematizing lesson study and its impacts: Studying a highly contextualised approach to professional learning, Teaching and Teacher Education, Vol 60, pp. $203-$ 214.

Hargreaves, A. \& Fullan, M. (2012). Professional capital: Transforming teaching in every school, Teachers College Press, New York.

Eng- Lee, K. \& Mun Ling, L. (2013), The role of lesson study in facilitating curriculum reforms, International Journal for Lesson and Learning Studies, Vol. 2 No. 3, pp. 200-206.

Kuno, H. (2015), Evolving the Curriculum Through Lesson Study in Japan in Lesson Study: professional learning for our time. Routledge, London.

Khokhotva, O. (2018), Lesson Study in Kazakhstan: case study of benefits and barriers for teachers, International Journal for Lesson and Learning Studies, Vol. 7 No. 4, pp. 250-262.

Lewis, C., \& Takahashi, A. (2013), Facilitating curriculum reforms through lesson study. International Journal for Lesson and Learning Studies, Vol. 2, No 3. pp. 207- 213.

Machamer, P. (2004), Activities and causation: The metaphysics and epistemology of mechanisms, International Studies in the Philosophy of Science, Vol.18, No. 1, pp. 27-39.

Machamer, P. , Lindley, D. \& Craver, C. (2000), Thinking about Mechanisms, Philosophy of Science, Vol. 67, No. 1, pp. 1-25.

Mayrhofer, E. (2019), Lesson study and teachers' beliefs: How a Bourdieuian perspective could make a difference, International Journal for Lesson and Learning Studies, Vol. 8 , No 1, pp.19-33.

Mishra, P. \& Koehler, M. (2006), Technological Pedagogical Content Knowledge: A Framework for Teacher Knowledge, Teachers College Record, Vol 108, No 6, pp. 1017-1054.

Mynott, J. (2019), Lesson study outcomes: a theoretical model, International Journal for Lesson and Learning Studies, Vol. 8, No 2, pp.117-13.

Nakano, H. (2008), Gakko Kaikaku no Shiteki Genzo [Historical model of school reform], Tokyo: Reimei Shobo.

Norwich, B. (2018), Making sense of international variations in lesson study and lesson study-like practices: An exploratory and conceptual perspective, International Journal for Lesson and Learning Studies, Vol. 7, No 3, pp.201-216.

OECD (2014) Reviews of National Policies for Education: Secondary Education in Kazakhstan. OECD, Paris

OECD (2016), Education at a Glance 2016: OECD Indicators, OECD Publishing, Paris, https://doi.org/10.1787/eag-2016-en.

OECD 2018 EDUCATION POLICY OUTLOOK KAZAKHSTAN http://www.oecd.org/education/EducationPolicy-Outlook-Country-Profile-Kazakhstan-2018.pdf

OECD (2018), Education Policy Outlook 2018: Putting Student Learning at the Centre, OECD Publishing, Paris, https://doi.org/10.1787/9789264301528-en.

OECD (2019), TALIS 2018 Results (Volume I): Teachers and School Leaders as Lifelong Learners, TALIS, OECD Publishing, Paris, https://doi.org/10.1787/1d0bc92a-en. 
Prenger, R., Poortman, C. \& Handelzalts, A. (2017), Factors influencing teachers' professional development in networked professional learning communities, Teaching and Teacher Education, Vol 68, pp. $77-90$.

Rappleye, J. \& Komatsu, H. (2017), How to make Lesson Study work in America and worldwide: A Japanese perspective on the onto-cultural basis of (teacher) education, Research in Comparative \& International Education, Vol. 12, No 4, pp. 398-430.

Robinson, N. \& Leikin, (2011), One teacher, two lessons; The lesson study process, International Journal of Science and Mathematics Education, Vol. 10, No. 1, pp. 139- 161.

SABER. (2013), Systems Approach for Better Education Results: Teacher Policy, Kazakhstan. The World Bank

Shamshidinova, K., Ayubayeva, N., \& Bridges, D. (2014), Implementing Radical Change: Nazarbayev Intellectual Schools as Agents of Change. In D. Bridges (Ed.), Educational Reform and Internationalisation: The Case of School Reform in Kazakhstan (pp. 71-82), Cambridge University Press, Cambridge.

Swaffield, S. (2004), Critical friends: supporting leadership, improving learning, Improving Schools, Vol. 7, No. 3, pp. 267-278.

Takahashi, A., \& McDougal, A. (2019), Using school-wide collaborative learning research to implement standards and improve student learning: Models and preliminary results. In R. Huang, A. Takahashi, \& J. P. da Ponte (Eds.), Theory and practice of lesson study in mathematics: international perspectives (Chapter 12). Springer Books.

Tan-Chia, L., Fang, Y. \& Chew Ang, P. (2013), Innovating the Singapore English Language curriculum through lesson study, International Journal for Lesson and Learning Studies, Vol. 2, No. 3, pp. 256280.

Vermunt, J., Vrikkia, M., van Halem, N., Warwick, P. \& Mercer, N. (2019), The impact of Lesson Study professional development on the quality of teacher learning. Teaching and Teacher Education, Vol. 81, pp. 61-73.

Webber, S. (2000), School, Reform and Society in the New Russia, Macmillan Press Ltd., London.

Wilson, E. (2016), Impact study of the Centre of Excellence Programme: Technical report МОНИТОРИНГ И ЭВАЛЮАЦИЯ ПРОГРАММЦЕНТРА ПЕДАГОГИЧЕСКОГО МАСТЕРСТВА Apollo University of Cambridge Repository 2018-02-01 | report DOI: 10.17863/CAM.12373.

$\mathrm{Xu}, \mathrm{H}$. , and Pedder, D. (2015), Lesson Study: an international review of the research, in Dudley, P (Ed.) Lesson Study: Professional Learning for our time, Routledge, London.

Yakavets, N., Frost, D. \& Khoroshash, A. (2017), School leadership and capacity building in Kazakhstan, International Journal of Leadership in Education, Vol. 20, No. 3, pp. 345-370. 


\begin{tabular}{|l|l|l|}
\hline T1: Starting Point & T2: CoE Intervention T3 & T4: Outcome \\
\hline Structural Conditioning & Social Interaction & Structural elaboration \\
\hline $\begin{array}{l}\text { Teacher led pedagogies } \\
\text { focusing on teacher } \\
\text { performance reluctant to } \\
\text { change. }\end{array}$ & Process Tracing analysis & $\begin{array}{l}\text { Active Lesson study embedded } \\
\text { in schools with teams of } \\
\text { teachers capable of internal } \\
\text { and external responding to } \\
\text { changes }\end{array}$ \\
\hline
\end{tabular}

Table one: Morphogenetic Change Sequence 


\begin{tabular}{|c|c|c|c|}
\hline & $\begin{array}{l}\text { Part 1: Mechanism } \\
\text { Developing and } \\
\text { extending teacher } \\
\text { professional knowledge }\end{array}$ & $\begin{array}{l}\text { Part 2: Mechanism } \\
\text { Collaborating to } \\
\text { develop professional } \\
\text { knowledge }\end{array}$ & $\begin{array}{l}\text { Part 3: Mechanism } \\
\text { Engaging in collective } \\
\text { inquiry to develop } \\
\text { professional knowledge }\end{array}$ \\
\hline \multirow[t]{2}{*}{$\begin{array}{l}\text { ACTIVITY } \\
\text { Reflexive, } \\
\text { Collaborative, } \\
\text { Collegial, } \\
\text { Knowledge } \\
\text { led, } \\
\text { Time } \\
\text { dependent. }\end{array}$} & $\begin{array}{l}\text { Cognitive dissonance with } \\
\text { current practice created by } \\
\text { accessing school data. } \\
\text { 'Buy in' to try new ways of } \\
\text { working to focus on pupils. } \\
\text { Professional support from a } \\
\text { more knowledgeable } \\
\text { critical friend. } \\
\text { Connecting theory and } \\
\text { practice. Apply knowledge. } \\
\text { TIME away from the school }\end{array}$ & $\begin{array}{l}\text { Trusting reciprocal } \\
\text { working relationships } \\
\text { established. Collaboration } \\
\text { between teachers at } \\
\text { different stages of their } \\
\text { career and more } \\
\text { knowledgeable } \\
\text { colleagues in different } \\
\text { schools and regions } \\
\text { Immediate evaluation of } \\
\text { change process. }\end{array}$ & $\begin{array}{l}\text { Collegial teams of well-trained } \\
\text { teachers and school leaders. } \\
\text { Identify a common problem, } \\
\text { think critically and work } \\
\text { towards a solution to be carried } \\
\text { out through Lesson Study. } \\
\text { Networking in and beyond } \\
\text { schools. }\end{array}$ \\
\hline & \multicolumn{3}{|c|}{$\begin{array}{l}\text { TIME in school to try out new ways of working } \\
\text { TIME to carry out extended dialogue with colleagues. } \\
\text { TIME for teachers to be reflexive and engage in internal conversations about practice } \\
\text { TIME to write about research study }\end{array}$} \\
\hline
\end{tabular}

\section{Entities: Social life of the classroom}

\begin{tabular}{|c|c|c|c|}
\hline $\begin{array}{l}\text { STRUCTURE } \\
\text { Leadership, } \\
\text { Grouping, } \\
\text { Access, } \\
\text { Methods. }\end{array}$ & $\begin{array}{l}\text { Extending knowledge } \\
\text { Extended blended face to face } \\
\text { and school - based training } \\
\text { with teachers from other } \\
\text { schools. } \\
\text { New ways of working with } \\
\text { readings and written support } \\
\text { materials } \\
\text { In school teacher action } \\
\text { research }\end{array}$ & $\begin{array}{l}\text { Collaboration } \\
\text { Teams of teachers who } \\
\text { coach peers and mentor } \\
\text { novices and other teachers. }\end{array}$ & $\begin{array}{l}\text { Collective enquiry: } \\
\text { Teacher learning communities in } \\
\text { schools using lesson study groups } \\
\text { as a key driver for classroom-based } \\
\text { research and development. }\end{array}$ \\
\hline $\begin{array}{l}\text { AGENCY } \\
\text { Individual } \\
\text { actions, } \\
\text { Collective } \\
\text { interactions, } \\
\text { Choices. }\end{array}$ & $\begin{array}{l}\text { Teacher collaboration and } \\
\text { support from critical friends. } \\
\text { Teachers' supported to } \\
\text { deliberate and reflect on } \\
\text { practice. } \\
\text { Teachers trusted to try out } \\
\text { new ways of working. }\end{array}$ & $\begin{array}{l}\text { Teachers co plan lessons } \\
\text { with coaches and observe } \\
\text { each other teaching. } \\
\text { Reflecting on what was } \\
\text { observed in professional } \\
\text { conversations about } \\
\text { practice. }\end{array}$ & $\begin{array}{l}\text { Teacher trusted to set up and run } \\
\text { school-based lesson study teams. } \\
\text { Teachers share the outcomes of } \\
\text { their work with other teachers } \\
\text { beyond their school through } \\
\text { practice journals and conferences. } \\
\text { LS teams empowered to develop } \\
\text { the professional learning of their } \\
\text { colleagues. }\end{array}$ \\
\hline $\begin{array}{l}\text { CULTURE } \\
\text { Intentionality, } \\
\text { Reasoned } \\
\text { motivation, } \\
\text { Beliefs, } \\
\text { values. }\end{array}$ & $\begin{array}{l}\text { Revised cultural script: with } \\
\text { time, space, evidence and } \\
\text { knowledge of new ways of } \\
\text { working it is possible to } \\
\text { change classroom practice. } \\
\text { Teachers are valued by the } \\
\text { school and are rewarded for } \\
\text { their work. }\end{array}$ & $\begin{array}{l}\text { Teachers are willing to open } \\
\text { up their practice to rational } \\
\text { scrutiny. } \\
\text { Willingness to change } \\
\text { practice. } \\
\text { Willingness to share } \\
\text { knowledge. }\end{array}$ & $\begin{array}{l}\text { Teachers focus their planning on } \\
\text { pupils' learning and believe they } \\
\text { are able to develop practice which } \\
\text { includes all learners. }\end{array}$ \\
\hline \multicolumn{4}{|r|}{$\gamma$} \\
\hline $\begin{array}{l}\text { EMPIRICAL } \\
\text { FINGERPRINTS, } \\
\text { OBSERVABLES }\end{array}$ & $\begin{array}{l}\text { Teachers' portfolios: including } \\
\text { detailed planning information, } \\
\text { pupil's work, action research } \\
\text { reports and reflective } \\
\text { accounts. }\end{array}$ & $\begin{array}{l}\text { Teachers' portfolios } \\
\text { including coaching and } \\
\text { mentoring plans. Teacher } \\
\text { evaluation of coaching plans } \\
\text { and access to reflective } \\
\text { accounts. Interviews }\end{array}$ & $\begin{array}{l}\text { Observation of Lesson study groups } \\
\text { in action in schools. } \\
\text { Reports and papers in journals } \\
\text { Presentations at conferences } \\
\text { Interviews with LS teams }\end{array}$ \\
\hline
\end{tabular}

Table two: Process tracing map of the three stages of the generative mechanisms 


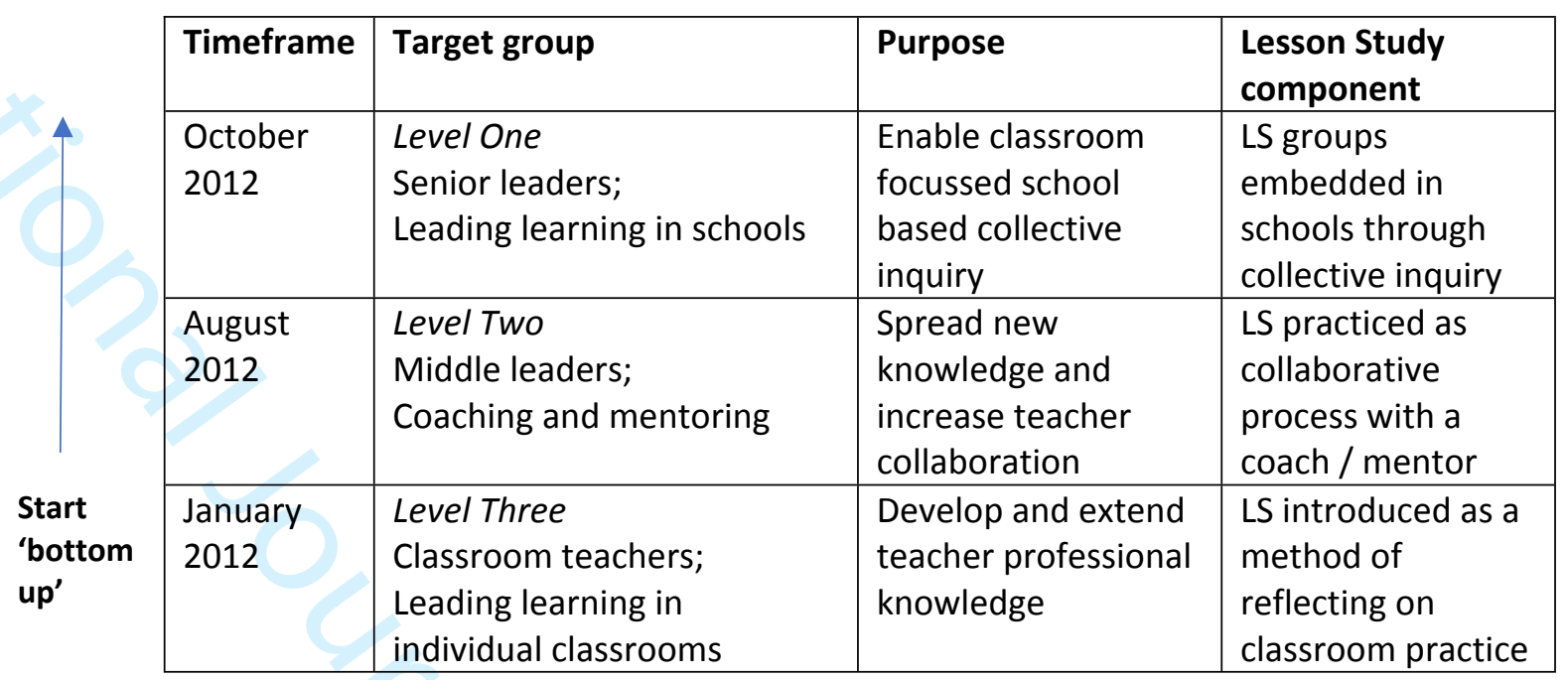


Figure 2: Time-line of introducing Lesson Study in Kazakhstan (Akimova \& Wilson, 2019)

\section{Lesson study} approach is implemented in the content of training

programs of the Center of Excellence

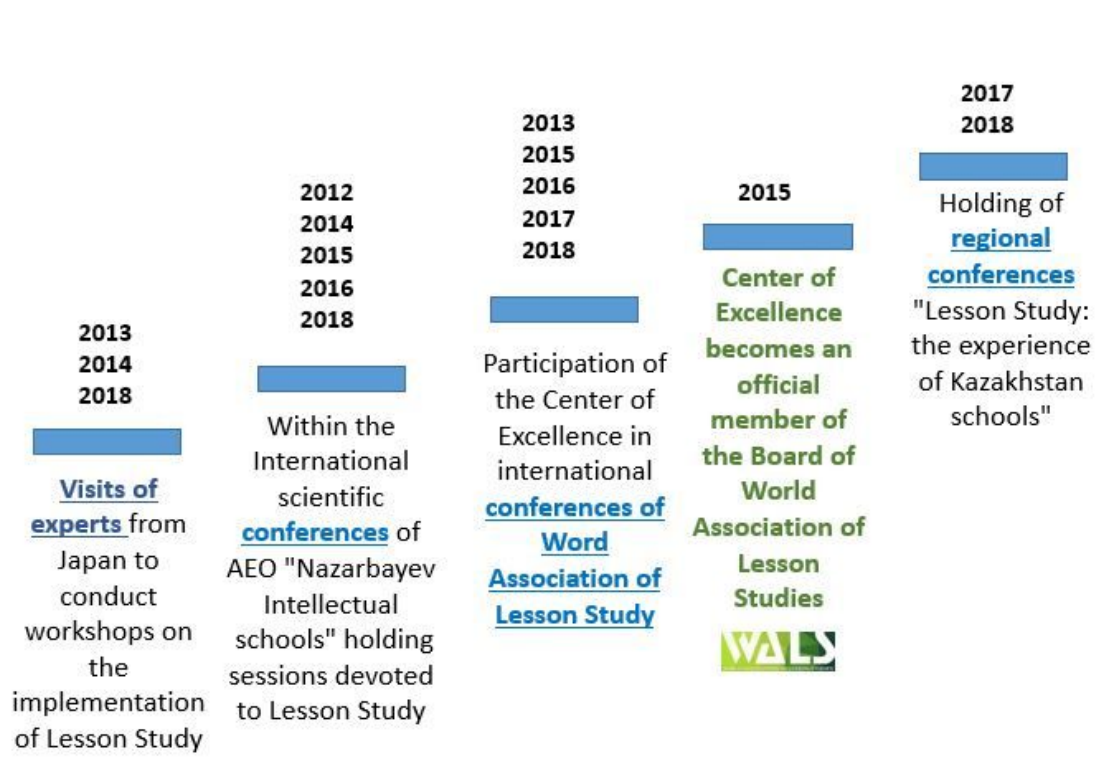

2018

2019

Training of school trainers and the introduction of intra-school professional development course

"Practice based inquiry" 


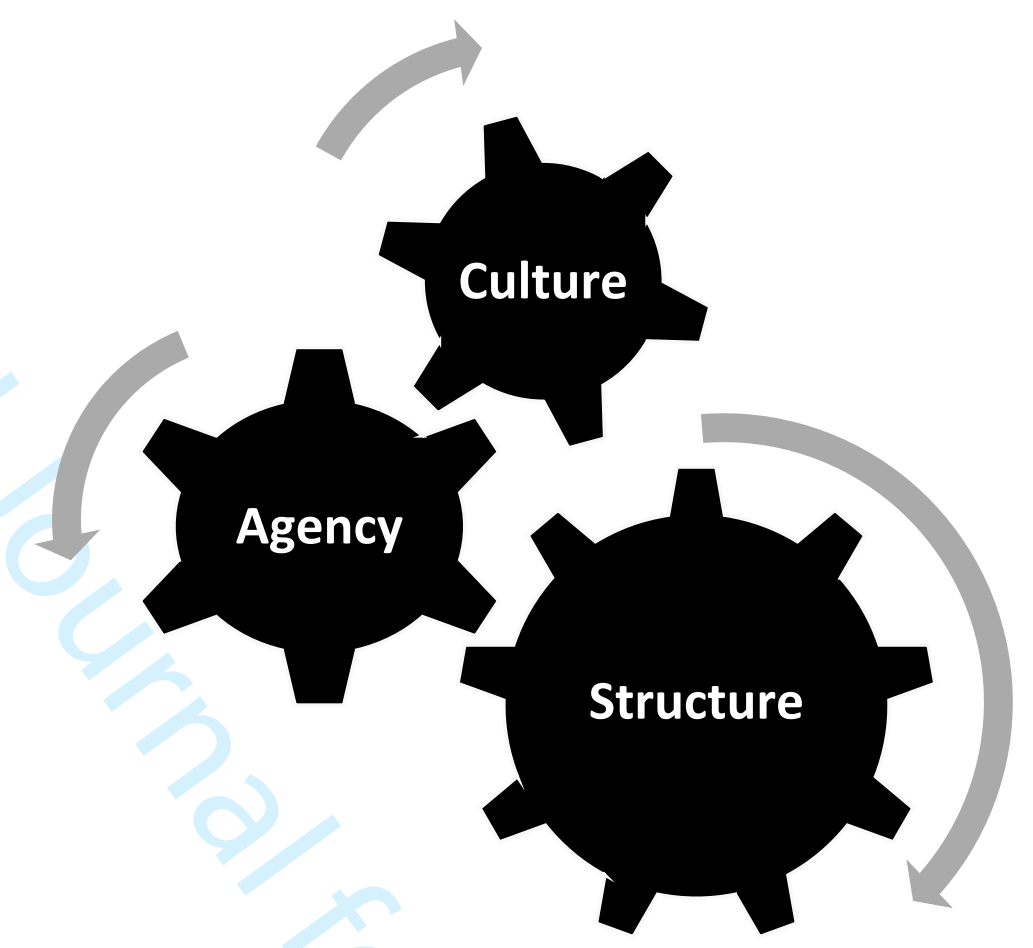

Figure 3: Theory building process tracing model. 